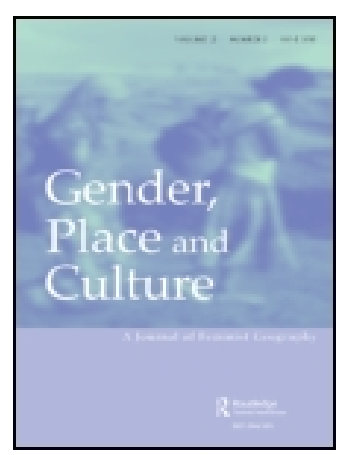

Gender, Place \& Culture

A Journal of Feminist Geography

ISSN: 0966-369X (Print) 1360-0524 (Online) Journal homepage: http://www.tandfonline.com/loi/cgpc20

\title{
'It's just a very male industry': gender and work in UK design agencies
}

\section{Suzanne Reimer}

To cite this article: Suzanne Reimer (2016) 'It's just a very male industry': gender and work in UK design agencies, Gender, Place \& Culture, 23:7, 1033-1046, DOI: 10.1080/0966369X.2015.1073704

To link to this article: http://dx.doi.org/10.1080/0966369X.2015.1073704 (c) 2015 The Author(s). Published by Taylor \&
Francis

曲 Published online: 03 Sep 2015.

Submit your article to this journal $\pi$

Llll Article views: 585

Q View related articles $\sqsubset$

View Crossmark data 


\title{
'It's just a very male industry': gender and work in UK design agencies*
}

\author{
Suzanne Reimer \\ Geography and Environment, University of Southampton, Southampton, UK
}

\begin{abstract}
The article focuses upon gender divisions of labour in the UK design sector as a means of highlighting a relatively understudied segment of the creative industries. Drawing upon a wider study of design consultancy firms across London, Birmingham, Manchester and Newcastle, it considers how configurations of gender division are bound up with everyday representations of design labour. The article reveals how associations between craft, skill and masculinity appear, and are reinforced in design practice. It also points to the ways in which design work is valorised within and through constructed geographies of difference between London and the regions, emphasising that hegemonic masculinities are reinforced and reproduced in reference to understandings of activities in place.
\end{abstract}

'Es que es una industria muy de hombres': género y trabajo en las agencias de diseño en el Reino Unido'

RESUMEN

El artículo se centra en las divisiones de género laborales en el sector de diseño del Reino Unido como medio para destacar un segmento relativamente poco estudiado de las industrias creativas. Basándose en un estudio más amplio de las firmas consultoras en Londres, Birmingham, Manchester y Newcastle, considera cómo las configuraciones de la división de género están estrechamente relacionadas con las representaciones cotidianas del trabajo del diseño. El artículo revela cómo las asociaciones entre el arte, la habilidad y la masculinidad surgen y se refuerzan en la práctica del diseño. También señala las formas en que el trabajo de diseño es valorado dentro y a través de las geografías construidas de las diferencias entre Londres y las regiones, enfatizando que las masculinidades hegemónicas son reforzadas y reproducidas en referencia a las formas de entender las actividades en el luqar.

\section{这是一个非常男性的产业': 英国设计公司中的性别与工作}

摘要

本文聚焦英国设计部门的劳动性别分工, 作为凸显创意产业中相对较少 受到研究的部分之方法。本文运用针对伦敦、伯明翰、曼彻斯特与纽卡 斯尔的设计咨询公司所进行之广泛研究, 考量性别分工的结构, 如何与 设计劳动的每日再现密切相关。本文揭露工艺、技术与男子气概之间的 联结, 如何在设计实践中展现并强化。本文同时指出, 设计工作如何透 过建构伦敦和其他区域之间的差异地理, 从而获得稳定, 并强调关乎理 解适切活动的霸权男子气概之强化与再生产。

\section{ARTICLE HISTORY}

Received 2 December 2014

Accepted 3 May 2015

\section{KEYWORDS}

Gender; design; masculinity; labour markets; craft; creativity

\section{PALABRAS CLAVES}

Género; diseño; masculinidad; mercado de trabajo; arte; creatividad

关键词

性别; 设计; 男子气概; 劳动 市场; 工艺; 创造力 


\section{Introduction}

Design as an industry and as a profession remains a relatively understudied segment of the creative and cultural industries. Through design, the creative process is registered via the production of objects, images, packaging or interiors: design 'bridges the concerns of aesthetics, manufacturing, purchasing and use ... in complex ways' (Sparke 2009, 10). This cross-cutting of art, aesthetics and commerce places distinctive demands upon designers, requiring that workers display and develop an array of skills associated with artistry, creativity and craft as well as managing relationships with those who procure design expertise, either within the context of an 'in-house' design team or by clients contracting for design services. It should be obvious that acknowledging sociocultural constructions of skill, craft and creativity is fundamental to understanding the working lives of designers, and that it is vital to attend to the power relations which create sharp patterns of labour market exclusion and division in the design sector. Marginalisation is constructed through cross-cutting dynamics of sexism, racism and discrimination by age and sexuality: the UK design profession remains distinctively white and male-dominated (Design Council 2005, 2010; Allen 2013). At the same time, gendered norms in the design industry appear almost taken for granted, not least by those who work within it. A female interviewee working for a London design consultancy firm, for example, shrugged her shoulders as she reflected: 'it's just a very male industry'.

The aim of this article is to understand the specific ways in which naturalised gender inequalities in design emerge and are reinforced, drawing upon a broader UK-based study of design agencies, or design consultancy firms, within London and three regional cities, Birmingham, Manchester and Newcastle. The study sought to capture the diversity of the sector, encompassing graphic design and branding as well as exhibition, interior and product design. ' I begin by drawing together important points of feminist critique in order to challenge continued silences about gendered power relations in design and the creative industries; and to contest accounts that assume gender-neutral, generic subjects, practices and social relations. Following an overview of the wider project on UK consultancy firms, my discussion explores everyday understandings of design labour. The article then investigates distinctive constructions of design as a form of craft, requiring specifically valued skills; and finally reflects upon the ways in which hegemonic masculinity - that is, a form of masculinity which is'most highly valued, legitimated, and respected in society' and which works to 'disempower women and to subordinate other men' (Bain 2009, 486) - is reproduced within and through the spaces and places of the UK design sector.

\section{Understanding gender divisions in design}

Given the distinctive nature of design, foregrounding the ways in which division and exclusion operate demands a careful assemblage of critique across an array of disciplinary and sub-disciplinary areas. Three key points of engagement are necessary for a developed feminist perspective on design. First, critical accounts of creative work and creative labour emerging from feminist sociology and cultural economy draw attention to workers themselves, rather than a potentially disembodied 'creative class' that has been the focus of much discussion. Such foregrounding not only of labour market insecurity, low levels of pay, a lack of career progression and pay (Gill 2002, 2009, 2010; McRobbie 2002, 2009; Oakley 2004, 2006, 2009; Ross 2008) but also clear patterns of gendered, racialised and classed inequality (Parker 2008; Negrey and Rausch 2009; Comunian, Faggian, and Li 2010; Leslie and Catungal 2012) stands in sharp contrast to a dominant geographical literature which has conceptually disregarded labour market exclusions. Despite the fact that advertising, design and architecture (for example) remain highly male-dominated sectors, they often continue to be evaluated using theoretical frameworks that rest upon gender-neutral understandings of learning, knowledge creation/exchange and indeed social interaction. ${ }^{2}$

Second, feminist challenges to a prevailing body of work within economic geography on innovation, entrepreneurship and networks are crucial to illuminate gendered power relations in design. Design often has been viewed as a key source of innovation (Vinodrai, Gertler, and Lambert 2007; Vinodrai 2013; Leavy 2010), potentially promoting the competitive advantage of nations, cities or regions 
(Bell and Jayne 2003; Bakhshi, McVittie, and Simmie 2008). Design also can be cast as entrepreneurial, in the sense that a large share of activity takes place within relatively small design consultancy firms operating across competitive environments of relatively rapid growth, dissolution and re-formation.

Analysts of innovation have emphasised its assemblage across a range of sites and spatial scales rather than being located solely within firms or individuals; and have foregrounded the importance of relational networks (Bunnell and Coe 2001; Amin and Cohendet 2004; Grabher and Ibert 2006). However despite the potential for attention to the socio-economic context of knowledge flows and exchange, dominant accounts have paid scant attention to gendered power relations within and across networks. As James $(2014,2)$ has emphasised, assessments of knowledge transfer amongst highly qualified workers, for example, commonly assume a genderless employee: 'workers' either have been viewed as generic and/or more general claims have been made on the basis of studies of male workers alone. Similarly, the subjects of entrepreneurship and innovation often are presented as largely gender-neutral (Blake and Hanson 2005; Hanson and Blake 2009; Ranga and Etzkowitz 2010). Such (mis)understandings make it difficult to foreground the sharp patterns of labour market exclusion and division (Oakley 2006, 265) that emerge as a result of unequal access to the social networks which commonly determine entry into and advancement within design.

Third, feminist work on creativity, design and craft assists in unpicking the ways in which design as a practice has been - and often continues to be - imbued with particular social constructions of masculinity (Bruce 1985; Lewis and Bruce 1989; Bruce and Lewis 1990; Allen 2013). Design skills often are naturalised; and in arenas where bodily ability is perceived to form a central part of skill, the potential aptitude of different bodies can be evaluated unequally. For example, in product design, the capacity to construct a physical prototype, to manipulate materials or even to use a hammer is often coded as essentially masculine, and a stereotyped separation of gender boundaries emerges (Clegg and Mayfield 1999). Further, as Parker $(2008,218)$ has emphasised, 'qualities such as creativity and talent are socially constructed characteristics often associated with privileged masculinity'. Attention to gender divisions is vital in order to understand the valorisation of certain types of knowledge and skill. It is highly ironic, for example, that conceptualisation of a mechanism such as tacit knowledge - which implicitly involves doing or being there (Gertler 2003) - is so effectively disembodied when a worker's gender is overlooked (see James 2014, 3). We need to reflect further upon how the idea of tacit knowledge itself-particularly to when it is associated with certain types of manual skill - may be implicitly coded as male. ${ }^{3}$

Design workplaces are distinctive in that they are strongly infused with masculinist assumptions bound up with ideas of 'craft', 'skill' and 'creativity'. The consistent connections between masculinity and craft as yet remain relatively understudied - despite implicitly gendered understandings of 'the craftsman' (Sennett 2009; Frayling 2011). ${ }^{4}$ Although artisanal craft skills (see Yanagisako 2002; Herzfeld 2003) might be seen to derive from innate ability or inherent bodily proficiency - and most commonly masculine/feminine dualisms are evoked - the gender coding of technical competences in design also has emerged at different points in history through everyday practices of exclusion (Callen 1980; Bruce 1985; Clegg and Mayfield 1999).

\section{The research: the UK design sector}

The wider research on which this article is based was carried out between 2005 and 2008 in London and three regional cities (Birmingham, Manchester and Newcastle), and involved 100 interviewees in 98 firms (two were joint interviews). Design firms were selected for interview in a stratified way to capture processes across a range of agency sizes and design specialisations: ultimately, firm type was prioritised over, for example, the age, gender or ethnicity of respondents. ${ }^{5} \mathrm{~A}$ central focus was to survey the relationship between London and secondary regional centres, including a consideration of the capacities for design firms outside London to attract new clients, to thrive; and to maintain profit margins. The capital retains a significant share of all design businesses (including consultancies, in-house teams and freelancers); and the largest, longest-established and most globally oriented firms are located in London (Design Council 2005). 
Because of the broader project's interest in firms and firm architectures, senior managers or directors were targeted for interview. Not surprisingly, this group was predominantly male: of 100 respondents, only 16 were women. Whilst the wider research thus prioritised the voices of a particular segment of the design labour force, a feminist analysis of this material does provide an opportunity to illuminate at least some of the ways in which masculinist power structures feed through to create sharp gender divisions in design.

Secondary data sources reveal considerable evidence of gender divisions in design. The Design Council $(2005,10)$ reported that $61 \%$ of designers and $79 \%$ of freelancers were men, whilst a follow-up study recorded that $60 \%$ of designers were male (Design Council 2010, 3). ${ }^{6}$ Gender imbalances are more substantial when design career trajectories are considered. Labour Force Survey data analysed by the Design Council (2005), for example, excludes design directors and managers - levels at which men predominate. A 2007 survey recorded that across all age groups $56 \%$ of designers were male, and that $64 \%$ of designers over age 35 were male (Billings 2007). Further, gender inequality can be stark between firms: the Design Council (2005) found that $46 \%$ of design consultancies were all-male.

Such visible patterns of gender inequality in design has shaped industry debate about 'gender bias' ("Focus on Gender Bias" 2006) and an absence of female design directors ("Women Can Make It" 2008; "It's the 21st Century" 2009; (see also "Parliamentary Group Addresses" 2006; "Voxpop: Women in Design" 2006; Billings 2007). As a function of a broader paucity of national-level data on design (see also Reimer, Pinch, and Sunley 2008), salary statistics are virtually absent, with little information about gender divides. Industry surveys have noted that creative directors' salaries typically are three times that of 'junior' designers and managing directors close to five times (Richardson 2009) which in conjunction with the workplace hierarchy noted above, contributes to a gendered pay gap (see also Harvey and Blackwell 1999).?

Moving beyond the broad sectoral contours of gender division, the article now turns to examine some of the ways in which design consultancy interviewees articulated and rehearsed assumptions about gender. I then reflect upon presumptions about the skills and qualities of designers which derive from distinctive constructions of design as a craft. Finally, to the extent that practices of hegemonic masculinity (Connell and Messerschmidt 2005; Bain 2009) are evident within design, I consider how we might understand the operation of exclusionary structures and practices through space and place (Berg and Longhurst 2003; Hopkins and Noble 2009). I follow feminist scholars who have understood hegemonic masculinity as underpinned 'through everyday social interactions' (McDowell 2000, 396 in reference to Mac an Ghaill 1996; see also Sang, Dainty, and Ison 2014).

\section{Everyday representations of design labour}

There is an enduring discourse in which the designer is normalised as male. Design 'teams' are referred to as 'the guys' and small firms as (for example) 'three-man' businesses. Typically, agencies are set up by one or two designers - often titled 'directors' or 'partners' - who own the firm and supervise the work of a small team of designers, in an arrangement not dissimilar to an artisanal workshop headed by a master craftsman. The sharp hierarchy of a small firm 'workshop' context, in which an owner/manager holds power and control, directly contributes to gender inequalities. Design jobs are conventionally advertised in the trade press as 'junior,' 'middleweight' and 'senior' - with the gendered inference of the boxing analogy going entirely unremarked.

As a means of opening up discussions about design knowledge, as well as the labour force and recruitment, interviewees were asked 'what makes a good designer?'In response, 'the designer' repeatedly and routinely was gendered as male:

you can get the brightest guy in the world, but if he isn't really interested or his attitude is not really focussed and he hasn't got any ambition, then you're not going to get out of him what you really need .... (managing director, male, Newcastle, product design)

The discussion implies that a senior manager's role is to encourage the development of personal'ambition' as well as to extract ('get out') particular forms of labour from employees. The inferred power 
relations are resonant with historic forms of workshop organisation reliant on (characteristically male) authority over a younger apprentice.

In a London branding firm, the male chief executive implied that a 'perfect' designer would have developed experience and expertise under tutelage, but yet still remain part of a youthful scene:

My perfect employee designer would be 32 years old, just young enough that he's still doing the scene, but old enough that he's actually got the wisdom to interpret it, and do something really, really great.

Here age and gender intersect as the interviewee underscores the desirability of a distinctive form of youthful sociability amongst his workforce. The unreflective gendering of the designer,'he', acts at least in part to characterise 'the scene' as a masculinised space.

Other interviewees explicitly emphasised the importance of (male) relationship in design. Interviewees commonly reported that client relationships were more important than inter-firm sociality, and a good designer was seen to be 'one who thinks about his customer and the audience' (design manager, male, Birmingham, branding). Crucially, however, the client also frequently was gendered as male:

I think a good designer's one that can answer the brief. Not necessarily design what you personally think is fantastic but what the client thinks he wants ... (co-director, male, Birmingham, interior design)

Expressed in this way, 'understanding the client' means understanding a male client and it is unquestioningly assumed that men will best be able to relate to other men. The development of rapport is seen to be important both to gaining new business, as a design firm initially'pitches' to a new client for a piece of work; and also it is viewed as crucial during the progress of a project, when a designer (and the firm) must work to complete a brief to the satisfaction of the client.

Alongside discursive constructions of the designer as male, gender divisions of labour are reproduced through recruitment. Consultancies needing to meet tight deadlines expressed a desire to maintain a good 'team atmosphere' (operations director, male, London product design). Within conversations about how firms found suitable employees, the following was typical: 'it's a lot about the personality and the fit' (managing director, male, Newcastle, branding and graphics). Ideas about 'fit' were not unconscious of gender, however. A London packaging design agency had a distinctive way of selecting employees, comparable to practices at elite male clubs:

I've really only had three people that I've had to get rid of and I think that's because I've been meticulous. We have a blackballing arrangement, in other words, somebody's going to join us ... and Luke who joined us a while ago, he got white balls all down the line, get that boy in! (managing director, male) ${ }^{8}$

Beyond the clubbable masculinity of the actual practice, the ways in which gender divisions emerge because employers recruit people 'like themselves' is key: 'it is at this stage that the particular characteristics and attributes sought in potential employees are made most clear' (McDowell 1997, 117).

Masculinities at work in design can be manifest in a degree of combativeness, if, for example, individual ideas about the direction of a project differ. The business development manager of a Birmingham graphic design firm commented:

Because we respect each other on all sorts of levels, we are able to be quite confrontational. I mean ... when men argue in business they sort the problem out and move. At the risk of sounding sexist, women will sometimes find it difficult to have that argument at work and not take it personally. And we've had some blazing rows here.

Close working relationships between colleagues have been described as a preponderance of 'strong ties': Sunley, Pinch, and Reimer $(2011,389)$ note that these 'play a key role ... within the agency as designers bounce ideas off one another in an intimate studio environment'. Yet as the interview quotation above emphasises, interactions may be marked by particular forms of masculinity which go largely unrecognised in the generic conceptualisation of 'strong ties'.

Everyday working practices within many creative industries can be seen to reproduce gender divides in the sense that women experiencing a 'double shift' at work and at home (Perrons 2003) face greater pressures and stress at work than do men - or indeed may be excluded from the labour force entirely (Gill 2002; Pratt and Jarvis 2006). A decline in numbers of women in the design workforce with age and an absence of women working in senior design management positions often is attributed to the impact of women's childrearing responsibilities. Beyond a quantitative assessment 
of numbers of women leaving the design workforce altogether, or remaining at lower levels in the profession, however, it is important to consider how senior design managers themselves represented this situation. The director of a London graphics and branding agency commented, for example: 'I suppose with all small companies we just have to accept the women within the company will go away and have babies after a while' (founder, male, London, branding and graphics). In discussion about a numerical gender imbalance in design, the male chief executive of a London branding agency suggested:'design businesses tend to be very small. Because they're small they find it difficult to take on the liability of someone who may go off and have a baby'. Although there is an awkward slippage between a gender-neutral 'someone' followed by a reference to the expected pregnancy of a female employee, the interviewee nonetheless unselfconsciously reproduced assumptions that maternity leave posed a fundamental problem for small firms, which made it entirely understandable to him that fewer women worked in design. ${ }^{9}$

Emphasis on being part of the 'team' classically meant working long hours to make sure that jobs were completed. In response to the question 'what makes a good designer?' one interviewee stated:

Enthusiasm .... Initiative ermm, it's always the design team that has to work late, it's always them. So a willingness to work you know, it has to be what's required you know and late hours and that kind of stuff. (senior designer, Birmingham, exhibition design)

As Parker $(2008,209)$ notes, 'cultures of "overwork", "competition" and masculinity' are closely associated within creative fields. In design agencies, intensive working in order to maintain not only firm, but also individual competitiveness was cited:

I have to work very hard at it [design] and I don't think there's some kind of magic formula. [...] we work very, very hard at it which sometimes is a bit of a killer ... like I said before ... there isn't a magic formula about putting a page together. I could spend an hour on it and maybe if I stayed until 2:00 in the morning I could make it 10\% better. So it's like a craft, you just have to keep working at it. (creative director, male, London, graphic design)

As Sang, Dainty, and Ison (2014) have emphasised for architecture, long and unpredictable working hours viewed as a professional norm are one of the ways in which hegemonic masculinity is reinforced and reproduced. There are two elements to long-hours cultures in design. First, there is an assumed requirement that creative work is all-encompassing. Workers must be obsessive or perfectionist in order to succeed, as implied in the quotation above (see Massey 1995). A second element within consultancies is an imperative to continually maintain or to develop new client relationships, which requires intensification in the workplace as well as 'extensification' beyond (Pratt and Jarvis 2006).

A small number of interviewees explicitly rejected dominant work cultures, expressing what Sang, Dainty, and Ison (2014) have characterised as forms of non-compliance with practices of hegemonic masculinity:

We hang on to staff as well because we don't work silly hours. A lot of design agencies have this sort of macho'My schedule's bigger than yours' sort of attitude to work. And if they haven't done an all-nighter once a week, they don't feel like they're a designer any more. (design director, male, Birmingham, branding and graphics)

This interviewee emphasised the positive effects on turnover achieved by moderating workload levels and employer expectations, whilst the design director of a London branding and graphics firm adopted fixed working hours of 9.30-6:00:

I mean on average I used to do 70 hours a week, you know, and that's ***ing bonkers, that's just silly and it's probably about 5 years ago we decided to make a change and to insist that people went home earlier and financially it meant that we'd lost the profit, but actually from a company point of view, it's much better. We haven't got people looking like they're half dead every day.

It may be that firms - such as the one above, which are longer-established and have stable client lists - have the resources to manage workflow in ways which do not require irregular and uneven working hours. However, the explicit rejection of a long-hours culture also appears to recognise that the performance of overwork - that is, working long hours for the sake of demonstrating stamina and 'competitiveness' - may in fact be counterproductive.

Other interviewees were reflective of how onerous working hours had negative impacts on their own family and personal life. The male interviewee who referred to female employees as presenting 'a 
liability' later suggested that long-hours cultures had led to the breakup of his marriage and the loss of close contact with his children:

I am struggling to hold this business together as it is. Demands. $60-80$ hours a week. Every week for the last 18 months, and you know, I lost a marriage because of it, and losing all else to boot. But it's like - what do you do? It's all I can do in my life. [...] I am lucky to [have got] to the top, but my options are very limited.

The head of a London-based exhibition design firm had plans in the early 1990 s to expand by acquiring a firm in Barcelona and setting up a studio in Singapore:

but then a range of recessions came along ... [...] And at the time l'd just had a young daughter born and looking back at it in hindsight, at which, if that had not come along, I am sure we would have achieved our goal, and I would have probably have seen very little of her for the first 5 or 6 years. I am pleased I did - er I am pleased it did fail in that respect.

Such comments may not necessarily challenge working norms at work in design, although they do reflect a level of acknowledgement of dominant practices. Whether or not there is potential for future change in the industry will depend in large part upon the how far new entrants to the design labour force are able to challenge existing patterns of discrimination. Although Nayak and Kehily's $(2008,98)$ work emphasises that for young school-age men and women, 'ideas about gender learning are dynamically processed, contested and culturally re-imagined,' Allen's (2013) study of work placements is much less optimistic about the experiences of young women seeking careers in design. ${ }^{10}$

\section{Masculinity, craft and design skill}

As feminist analyses of gender, technology and skill consistently have demonstrated notions of 'skill' itself frequently are reworked to reward male workers (Cockburn 1983; McDowell 1991). Associations between technology and masculinity have been persistent; and within male-dominated sectors and professions, women's technical expertise frequently is questioned (Ranga and Etzkowitz 2010; Nafus 2012; Sang, Dainty, and Ison 2014). The gender coding of'skill' is rarely unpacked: skill in waged labour is commonly represented generically, although there is significant evidence of its undervaluing when held by women. As Gill $(2002,82)$ reports, 'inequalities persisted once women entered the field of new media, even when they had equivalent levels of IT skills to their male contemporaries'.

Banks and Milestone $(2011,81)$ have expressed this gendered devaluing of skill in new media as the allocation of women to secondary (non-creative) roles:

by and large women were only seen as being able to counterbalance male innovation and creativity by taking on supporting roles that befitted their 'natural' gender attributes. Male managers repeatedly denied that women possessed legitimate expertise in creative or technological production.

Whilst Jenson's (1989) distinction between natural and innate feminine 'talents' versus acquired 'skills' (coded as masculine) is useful for understanding the undervaluing of women's work, there is also a sense in which creative skill in design is itself constructed as male. Although men are able to acquire technical competences via craft working or apprenticeship, they also are seen to possess instinctual capabilities for creativity.

Historically, men and women have been sorted into different types of design employment, with women predominating in interior design, for example, whilst product design - often seen to require 'a particular sort of masculinity rooted in industrial tradition' - is male-dominated (Clegg and Mayfield $1999,9)$. A growing number of women have gained qualifications in graphic design, although in this sub-discipline associations between masculine artistry and aesthetic ability have had an exclusionary effect when female graduates seek to move into the design workforce. Allen's (2013) account of women graphic design students on work placements, for example, revealed overwhelming experiences of being a body'out of place' or as one which was 'infiltrating' or 'contaminating' a dominantly male environment. What Clegg and Mayfield refer to as the 'stereotyped demarcation of gender boundaries' in design relies on fixed associations: a student interviewee, for example, sought to emphasise interest in the structural and architectural knowledges required for interior design and refuted 'feminine' expertise in 'soft furnishings' (1999, 10). 
There is a broadly held view that constructs design strongly as a craft. Despite significant technological developments, many interviewees made reference to and indeed celebrated the notion of 'tradition' and 'craft' skill, emphasising the need for designers to be able to draw freehand with a pen or pencil; to have a detailed grasp of typography; or to understand the mechanics of the printing process: 'there's not enough people who understand the basics, really' (studio manager, male, Birmingham, graphic design). Product designers were concerned about new entrants being only being able to 'think' in two dimensions instead of three as a result of computer technologies. The male head of a Newcastle branding and communications company lamented a lack of printing/typesetting knowledge: 'you can put a job to press, coming back, it's bloody awful and the client goes "I ain't paying for that" and you invariably find that students don't understand print properly.'This interviewee's training had involved the physical experience of printing, mixing colours and setting out type: in his view it was important to know 'what printers do, all the guys who are the printers.'

This valorisation of learning 'traditional' - and notably in the case of typesetting and printing strongly masculinised - craft skills potentially acts to reinforce hegemonic masculinity, particularly in combination with the repeated normalisation of 'the designer' as male. However there is also a sense in which forms of intuitive, un-taught creativity are viewed as masculine. The male director of a branding and communications firm in Newcastle delineated what he expected from new graduates:

I think they don't necessarily have to be able to draw, but what they have to be aware of is, they have to have a ... you kind of meet people who have an intuitive eye of things ... it's like a painter who puts something down and it looks nice because he has an eye for what looks aesthetic and its balance and its proportions and its colour and its position in the frame, looks nice, and I think designing something is exactly the same thing.

Ostensibly, the new employee is represented as generic 'people', but requisite abilities are associated with the artistic and aesthetic skills of a male painter. The'he' is not incidental: it reinforces social definitions of masculine creativity (Pollock 1983). Whilst few were as explicit as the interviewee who asserted:'I might piss you off saying this but I genuinely believe that men are better designers than women.' (chief executive, male, London, branding), the 'embedded gender norms and constructions of the "creative person" as a masculine subject' described by Allen $(2013,233)$ can be difficult for women to navigate.

\section{Inferred geographies of labour market experience: hegemonic masculinity and regional divides in design}

The penultimate section of the article reflects upon perceptions of emergent divisions between geographically different types of design labour market. My emphasis is upon what were seen to be divergent design labour market experiences in different parts of the UK. In conversations about staff turnover and career trajectories, a noteworthy narrative emerged which contrasted working patterns in the fastpaced capital city with what were considered to be less-demanding 'provincial' settings. Sometimes, this was expressed as workers wanting to move away from London for reasons of 'lifestyle' or 'family responsibility. At other times, provincial settings were openly derided for producing lower calibre design work compared with London firms. This was explained either in the sense that non-London firms were'less competitive' or was attributed to less exacting and/or less knowledgeable clients in 'the regions'. Narratives registered an interesting disparity between what was coded as a highly masculine, competitive way of working in design in London; and experiences within less 'strenuous' environments. One London interviewee commented:'you don't need to be quite so good if you're in Newcastle' (male, branding and graphics). As Hanson and Blake $(2009,138)$ have emphasised, both institutions and individuals (as employers) often conceive of gender difference in 'stark, binary, essentialised terms,' even as individual employees navigate much more fluid experiences of identity. The aim in this section is to foreground how gendered ideologies and norms which buttress ideas about hegemonic masculinity are crafted through reference to regional and spatial difference. ${ }^{11}$

The male director of a large London packaging design firm talked at length about different types of turnover at his agency. He reported that some employees started work in their early twenties and remained with the firm a long time. As employees moved into their thirties, design workers 'start[ed] to shake out into different groups.'The first of these turned out to be women who had left the design profession: 
you know, quite a few of them start to think about families and children and particularly the women obviously that can mean you lose some of them, well we lose probably three out of four of the people who have children, so relatively few working mothers here.

Then:'you get quite a few lifestyle choices for the other lot [i.e. not mothers] and some of it is actually an anti-London effect.' A combination of high housing costs, high living expenses and commuting pressures meant that 'we lose some of them to the provincial design firms.'

Repeated references to 'lifestyle' might be seen to refer to what feminists would understand as the impact of lifecycle changes, including starting a family. However, there are a number of distinctive aspects to designers' comments about 'lifestyle choices.' First, the reference most frequently was to male designers who at a certain stage of their career, had moved both job and family outside of London. Secondly, there were often relatively strong implications - particularly when mention was made of the move to a 'provincial' or a 'parochial' setting - that a 'lifestyle' move involved a rejection of the 'high-pressure' world of design in London. 'Lifestyle choices' were effectively a trade-off of the 'exciting' for something slower and by implication easier.

The director of a large London branding agency contrasted design consultancy employment with working for an in-house design team. He suggested that employees who were 'just not quite good enough' for his firm had moved to 'easier' in-house design work for retailers, in which they (reportedly) worked 9-5, took'a proper hour for lunch [...] and the pressure is considerably less, you know they do one project a fortnight whereas here they've got three on the go all the time.'Initially, the interviewee referred to the departure of male staff: 'ultimately you have to be tough enough to say, you know, I'm sorry son you're not good enough to compete at this level in this organisation on this type of work'. However, he later implied that the choice of an 'easier lifestyle' was taken up by women with children.

So it's an easier lifestyle and you'll find quite a lot of people who've got children, women with children will actively therefore accept the less stimulating environment because they are working for one organisation and to an extent they are kind of rolling it out. [...] it's a lifestyle choice really and often [retailers'] design studios aren't based in London.

The pattern of 'lifestyle choice' is associated with a departure from (a valorised) hegemonic masculinity, as both male and female designers moving from a consultancy to a regional or 'outside London' in-house team are broadly disparaged for moving to a'less stimulating' (read by the interviewee as less creative) environment.

In a discussion of the extent to which place might fuel possibilities for creativity, the male director of a large London product design firm commented:

I've got friends who live in Norwich, it's just a different ... they're not even on the same planet frankly, how can they be? They read the newspapers and look at the mags and all the rest of it, but they're not going to events and listening to things and they're not going to the theatre, [...] if they don't come to London, you quickly become parochial.

At one level, the interviewee suggests that the achieved success of his own (considerably sized) firm is possible only in London - and certainly there is evidence that client relationships may be most easily grown and sustained in London. However, there is also a sense in which design work is seen to suffer from being 'too far' from the capital, in part because designers are not able to infuse themselves with London-based sources of creativity. ${ }^{12}$

One interviewee made a fascinating association between the busy, crowded atmosphere of London and an impetus for creativity:

when I was in Bath I found it unbelievably slow. And actually quite bad for my work ethic, and perhaps it's because I'm a Londoner and I felt often very, very lethargic! [...] it's almost like the struggle in London, the difficulties kind of give you an impetus that you need in order to get things done, which is really weird. [...] it's a kind of struggle thing that makes you really - by the time you get to work [on crowded public transport] you're like really geared up and you have to fight your way to work, and it has an effect on - and it worries me, it really worries me, because I think it is quite unpleasant need in a way. (partner, female, London, graphic design)

This designer is disconcerted by the idea of seemingly needing a combative environment to sustain a burst of creative working - but at the same time reads the perceived slowness of Bath as a barrier to effective design practice. 
At a broad level, the narratives I have highlighted act to essentialise a binary between a hegemonically (even heroically) masculine London in contrast to a regional imaginary connoted as an other-than-masculine space. Although discourses appear fixed and oppositional, it is important to register that interviewees actively produce these imaginations of particular places. Some of the strongest statements about the 'stimulation' provided by a competitive 'London' location in fact were made by interviewees based in suburban locations to the west of the capital, rather than stereotypically 'buzzy' environs of East London such as Hackney or Dalston. What is most significant is the representation of geographical difference through an imagined opposition between 'London' and 'the regions'. Attention to these inferred geographies provides a means to open up discussions about the ways in which practices of hegemonic masculinity have the potential to be filtered through space and place.

\section{Conclusions}

This article has focused upon a distinctive form of creative labour - design - in order to explore the emergence and reinforcement of configurations of gender division in UK design consultancy firms. I have foregrounded how understandings of creativity, knowledge, innovation and craft may be presented in a gender-neutral guise but in fact often rest on assumptions about a distinctively masculine subject; and I have reflected upon the ways in which understandings of that masculine subject emerged in conversations with designers. Discussions typically resonated with Kelan's study of information technology firms, in which employees struggled to 'make sense of a masculine work environment', displaying frequent hesitation and punctuating statements with 'I don't know why ...' or 'it's just ...' $(2007,502)$. Ultimately, a'natural' gender order is reinforced as respondents spoke about design employees, whether emphasising an anomalous gender-neutrality, or shifting quickly from characterisations of a generic worker to accounts of 'the designer, he ...'

The approach in this article also has been to uncover inequalities that as Gill $(2014,6)$ has argued 'are neither accidental nor incidental but produced by the labouring conditions themselves'. Design masculinities are rehearsed through, for example, the normalisation of long and unpredictable hours; and via relationships developed in the work setting and with clients. The article has sought to reveal how associations between craft, skill and masculinity appear, and are reinforced in design practice. Finally, I have pointed to the ways in which design work is valorised within and through inferred geographies of difference between London and the regions, emphasising that hegemonic masculinities are not established on the head of a pin but are rather reinforced and reproduced in reference to understandings of activities in place.

The synthesis offered in this article - drawing together feminist approaches to creative work and creative labour; perspectives on innovation and networks; and understandings of creativity, craft skill and masculinity - is vital in order to challenge continuing silences about gender and indeed to de-legitimise the exclusions generated in design. Three decades ago, Sayer and Morgan $(1985,167)$ voiced a sharp critique of understandings of regional development which prioritised the 'relatively bloodless categories of aggregate statistics'. Yet an analogous inattention to bodily corporeality remains within much writing on creativity, innovation, learning and networks. The dangers of overlooking gender division and exclusion are revealed starkly in Nafus' (2012) account of open-source software development. In contrast to the citation of these particular 'knowledge communities' as providing possibilities for 'openness' or reflecting forms of democratic'co-creation', Nafus (2012) reveals the entrenchment of deeply sexist social relations and practices, including misogynistic'flaming'.

Gill $(2014,1)$ has emphasised the subtle inscription of sexism in the creative workplace, including claims that gender inequality has been overcome. Amongst design interviewees, it was recurrently emphasised that gender divisions were 'getting better':

... of 16 people we've got 3 females in senior positions and 3 females in junior positions so it's a fairly even balance and it's what, 60/40, something like that which I think is quite reasonable. (chief executive, male, London, branding and graphics) 
The disavowal of structural power relations (Gill 2014,3) is highly problematic, not least because of enduring configurations of exclusion in design. Writing close to 25 years ago, Bruce and Lewis (1990, 120) challenged the overrepresentation of 'white males with middle-class values'; and called for more evidence of 'the barriers women face as designers'. Beyond the illumination of barriers, however, this article has called for an explicit recognition of everyday representations of and assumptions about design labour as well as for conceptual attentiveness to gender divisions in creative labour, both of which contribute to making design 'a very male industry.'

\section{Notes}

1. Fashion, furniture and jewellery design are not discussed because they did not form part of the research on which the article is based - they rarely take place within a consultancy setting; are more closely entwined with their respective commodity networks; and workforces are often engaged in the relatively different dynamic of designer-making. On jewellery and craft, see Hughes (2012).

2. See, for example, Grabher (2001, 2004), Grabher and Ibert (2006), Faulconbridge (2010), Cohendet et al. (2014).

3. Consider, for example, Strati's (1999) account of roofing workers, which foregrounds specific forms of bodily effort and dexterity without any reflection upon the cultural coding of such skills as masculine - even as he refers repeatedly to 'workmen'.

4. Sennett superficially registers craft skill as gender-neutral, writing that 'we might think that a good craftsman, be she a cook or a programmer ...'; and exhorts the reader to consider parenting as a craft $(2009,26$ and 23). The implications of this gender-neutrality, however, means that his analysis ultimately fails to acknowledge any forms of gendered power dynamics. A celebration of the sociability of medieval guilds is entirely without reference to potential gender divisions, even as it depicts the 'face-to-face authority' of a male-dominated craft workshop setting (Sennett 2009, 246).

5. Given the qualitative nature of the research as well as an absence of a comprehensive database of firms from which to select at random, the sample was not representative but rather sought to include types of agencies that might be numerically small but of important conceptual interest, such as product design firms (Sunley, Pinch, Reimer and Macmillen 2008, 678).

6. Only $6 \%$ of designers were 'from minority ethnic groups' (Design Council 2005, 10). Whilst the stark whiteness of the industry is not the central focus of this article, there is a need for further analysis of the ways in which spaces of design are naturalised or normalised as both white and male (see especially Puwar 2004).

7. Job titles are often inconsistent across the diversity of design agencies, but in general a creative director manages 'junior,',middleweight' and 'senior' designers (see discussion in the following section), whilst a managing director oversees accounts, new business departments and artwork/design roles across the whole firm. In the $74 \%$ of firms employing fewer than five designers (Design Council 2010,31), management roles significantly converge leading to sharper disparities between 'designer' and 'manager' salaries.

8. Blackballing is a form of secret ballot in which a white ball signifies support of a candidate and a black ball constitutes rejection. Historically, it has been used to admit members to gentlemen's clubs or secret (male) societies such as the Freemasons. In the quotation, Luke is a pseudonym.

9. A counter-argument was presented by the female director of a London graphic design firm, who reacted strongly to this dominant attitude about maternity leave: 'It's not difficult really! Because it is something you can plan for. It's all about how you deal with it.'

10. A longitudinal investigation of career trajectories for women in design, tracking career moves over time, would provide a fascinating window on possibilities and prospects for change.

11. It is also important to be cognisant of the potential for recurrent characterisations of the 'strenuous' and 'competitive' London working environment to map on to corresponding pay differentials. Whilst data limitations prevent a comprehensive analysis of this point, it seems that London design managers' salaries are disproportionately larger: Richardson (2009) indicates that there is a 20-30\% difference between London and 'outside London', whilst junior designers' salaries differ by less than $7 \%$.

12. Whilst there has been considerable work on relationships between place and creativity, I am most interested here in how interviewees' narratives register assumptions about difference between London and 'the regions'. That is, the very city which 'becomes a critical input into the production process' (Rantisi 2004, 92) is constituted at least in part through imaginations and representations of 'London' and not primarily through the direct registering of place-specific sources of 'creativity' (cf. Drake 2003).

\section{Acknowledgements}

Many thanks to seminar audiences at the Department of Anthropology, National University of Ireland, Maynooth and the Centre for Urban and Regional Development Studies (CURDS), University of Newcastle, who provided helpful comments 
on the presentation of earlier versions of the paper. I am indebted to Alison Bain and Taylor Bridges for readings of a draft circulated at the Third European Colloquium on Culture, Creativity and Economy; and also would like to thank Pamela Moss and three anonymous referees for very constructive comments and suggestions. All arguments in this paper are my own.

\section{Disclosure statement}

No potential conflict of interest was reported by the author.

\section{Funding}

The research on which the paper draws was supported by the Economic and Social Research Council under [Award No. 062-23-0083] (with Peter Sunley and Steven Pinch) and by an Annual Grant from the University of Southampton.

\section{Notes on contributor}

Suzanne Reimer is Associate Professor in Geography at the University of Southampton. Previous research projects include a UK Economic and Social Research Council-funded study of British design consultancy firms in London and the regions (with Peter Sunley and Steven Pinch); and an investigation of commodity chains in the household furnishings industry with Deborah Leslie (University of Toronto), funded by the ESRC and the Social Sciences and Humanities Research Council of Canada. Suzanne Reimer is interested in aspects of design, creativity and knowledge, including the gendering of creativity, craft and design labour; and the role of design in commodity networks. She has ongoing interests in the furniture industry, in modernism and design, and in moto-mobilities.

\section{ORCID}

Suzanne Reimer (D) http://orcid.org/0000-0001-7325-4368

\section{References}

Allen, Kim. 2013. "'What Do You Need to Make it as a Woman in this Industry? Balls!': Work Placements, Gender and the Cultural Industries." In Cultural Work and Higher Education, edited by Daniel Ashton and Caitriona Noonan, 232-253. Basingstoke: Palgrave Macmillan.

Amin, Ash, and Patrick Cohendet. 2004. Architectures of Knowledge: Firms, Capabilities and Communities. Oxford: Oxford University Press.

Bain, Alison L. 2009. "Masculinism." In International Encyclopaedia of Human Geography, edited by, Rob Kitchin and Nigel Thrift, 486-491. Amsterdam: Elsevier.

Bakhshi, Hasan, Eric McVittie, and James Simmie. 2008. Creating Innovation: Do the Creative Industries Support Innovation in the Wider Economy? Research Report, National Endowment for Science, Technology and the Arts (NESTA), London.

Banks, Mark, and Katie Milestone. 2011."Individualization, Gender and Cultural Work." Gender, Work \& Organization 18: $73-89$.

Bell, David, and Mark Jayne. 2003. "Assessing the Role of Design in Local and Regional Economies." International Journal of Cultural Policy 9: 265-284.

Berg, Laurence, and Robyn Longhurst. 2003. "Placing Masculinities and Geography." Gender, Place and Culture 10: 351-360.

Billings, Scott. 2007. "Salterbaxter Report Reveals Lack of Diversity in Design." Design Week, March 15.

Blake, Megan, and Susan Hanson. 2005. "Rethinking Innovation: Context and Gender." Environment and Planning A 37: 681-701.

Bruce, M. 1985. "A Missing Link? Women and Industrial Design." Design Issues 6: 150-156.

Bruce, Margaret, and Jenny Lewis. 1990. “Women Designers: Is There a Gender Trap?" Design Studies 11: 114-120.

Bunnell, Tim, and Neil Coe. 2001."Spaces and Scales of Innovation." Progress in Human Geography 25: 569-589.

Callen, Anthea. 1980. "Sexual Division of Labour in the Arts and Crafts Movement." Oxford Art Journal 3 (1): 22-27.

Clegg, Sue, and Wendy Mayfield. 1999. "Gendered by Design: How Women's Place in Design Is Still Defined by Gender." Design Issues 15: 3-16.

Cockburn, Cynthia. 1983. Brothers: Male Dominance and Cultural Change. London: Pluto Press.

Cohendet, Patrick, David Grandadam, Laurent Simon, and Ignasi Capdevila. 2014. “Epistemic Communities, Localization and the Dynamics of Knowledge Creation." Journal of Economic Geography 14: 929-954.

Comunian, Roberta, Alessandra Faggian, and Quian Cher Li. 2010. “Unrewarded Careers in the Creative Class: The Strange Case of Bohemian Graduates." Papers in Regional Science 89: 389-410.

Connell, R. W., and J. W. Messerschmidt. 2005. "Hegemonic Masculinity: Rethinking the Concept." Gender and Society 19: 829-859. 
Design Council. 2005. The Business of Design. London: Design Council.

Design Council. 2010. Design Industry Research 2010. London: Design Council.

Drake, Graham. 2003. "'This Place Gives Me Space' Place and Creativity in the Creative Industries." Geoforum 34: $511-524$.

Faulconbridge, James. 2010. "Global Architects: Learning and Innovation Through Communities and Constellations of Practice." Environment and Planning A 42: 2842-2858.

Frayling, Christopher. 2011. On Craftsmanship. London: Oberon.

"Focus on Gender Bias is Fuelled by Political Correctness Correspondence from Barry Stedham." 2006. Design Week, July 20.

Gertler, Meric S. 2003. "Tacit Knowledge and the Economic Geography of Context, or The Undefinable Tacitness of Being (There)." Journal of Economic Geography 3: 75-99.

Gill, Rosalind. 2002. "Cool, Creative and Egalitarian? Exploring Gender in Project-based New Media Work in Europe." Information, Communication and Society 5: 70-89.

Gill, Rosalind. 2009. "Creative Biographies in New Media: Social Innovation in Web Work." In Creativity and Innovation, edited by. P. Jeffcutt and Andy Pratt, 161-178. London: Routledge.

Gill, Rosalind. 2010. "'Life is a Pitch': Managing the Self in New Media Work."In Managing Media Work, edited by Mark Deuze, 249-262. London: Sage.

Gill, Rosalind. 2014. "Academics, Cultural Workers and Critical Labour Studies." Journal of Cultural Economy 7: 12-30.

Grabher, Gernot. 2001. "Ecologies of Creativity: The Village, the Group and the Heterarchic Organisation of the British Advertising Industry." Environment and Planning A 33: 351-374.

Grabher, Gernot. 2004. "Learning in Projects, Remembering in Networks? Communality, Sociality and Connectivity in Project Ecologies." European Urban and Regional Studies 11: 103-123.

Grabher, Gernot, and Oliver Ibert. 2006. "Bad Company? The Ambiguity of Personal Knowledge Networks." Journal of Economic Geography 6: 251-271.

Hanson, Susan, and Megan Blake. 2009. "Gender and Entrepreneurial Networks." Regional Studies 43: 135-149.

Harvey, Lee, and Alison Blackwell. 1999. "Gender Bias in Incomes of UK Art and Design Graduates." Industry and Higher Education 13: 323-329.

Herzfeld, Michael. 2003. The Body Impolitic: Artisans and Artifice in the Global Hierarchy of Value. Chicago, IL: University of Chicago Press.

Hopkins, Peter, and Greg Noble. 2009. "Masculinities in Place: Situated Identities, Relations and Intersectionality." Social and Cultural Geography 10: 811-819.

Hughes, Christina. 2012. "Gender, Craft Labour and the Creative Sector." International Journal of Cultural Policy 18 (4): $439-454$.

"It's the 21st Century - Where Did All the Female Directors Go? Correspondence from Bob Wallace." 2009. Design Week, June 25.

James, Al. 2014. "Work-life 'Balance' and Gendered (im)Mobilities of Knowledge and Learning in High-tech Regional Economies." Journal of Economic Geography 14: 483-510.

Jenson, Jane. 1989. "The Talents of Women, the Skills of Men: Flexible Specialisation and Women." In The Transformation of Work? Skill, Flexibility and the Labour Process, edited by Stephen Wood, 127-140. London: Unwin Hyman.

Kelan, Elizabeth K. 2007. "I Don't Know Why' - Accounting for the Scarcity of Women in ICT Work." Women's Studies International Forum 30: 499-511.

Leavy, Brian. 2010. “Design Thinking - A New Mental Model of Value Innovation." Strategy and Leadership 38: 5-14.

Leslie, Deborah, and John Paul Catungal. 2012. "Social Justice and the Creative City: Class, Gender and Racial Inequalities." Geography Compass 6: 111-122.

Lewis, Jenny, and Bruce, Margaret. 1989. "Divided by Design: Gender and the Labour Process in the Design Industry." The Open University/UMIST Design Innovation Group, Working Paper CP-08.

Mac an Ghaill, M., ed. 1996. Understanding Masculinities: Social Relations and Cultural Arenas. Buckingham: Open University Press.

Massey, Doreen. 1995. "Masculinity, Dualisms and High Technology." Transactions of the Institute of British Geographers 20: 487-499.

McDowell, Linda. 1991. "Life without Father and Ford: The New Gender Order of Post-Fordism." Transactions of the Institute of British Geographers 16: 400-419.

McDowell, Linda. 2000. "Learning to Serve? Employment Aspirations and Attitudes of Young Working-class Men in an Era of Labour Market Restructuring." Gender, Place and Culture 7: 389-416.

McDowell, Linda. 1997. Capital Culture: Gender at Work in the City. Oxford: Blackwell.

McRobbie, Angela. 2002. "Clubs to Companies: Notes on the Decline of Political Culture in Speeded up Creative Worlds." Cultural Studies 16: 516-531.

McRobbie, Angela. 2009. "Precarious Work in the Cultural Industries." In Governance der Kreativwirtschaft : Diagnosen und Handlungsoptionen, edited by B. Lange, A. Kalandides, B. Stober, and I. Wellmann, 123-139. Bielefeld: Transcript Verlag.

Nayak, Anoop, and Mary Jane Kehily. 2008. Gender, Youth and Culture: Young Masculinities and Femininities. Basingstoke: Palgrave Macmillan.

Negrey, Cynthia, and Stephen D. Rausch. 2009. “Creativity Gaps and Gender Gaps: Women, Men and Place in the United States." Gender, Place \& Culture 16: 517-533.

Nafus, Dawn. 2012. "'Patches don't have Gender': What is Not Open in Open Source Software." New Media \& Society 14: 669-683. 
Oakley, Kate. 2004. "Not so Cool Britannia, the Role of Creative Industries in Economic Development." International Journal of Cultural Studies 7: 67-77.

Oakley, Kate. 2006. "Include us Out - Economic Development and Social Policy in the Creative Industries." Cultural Trends 14: 283-302.

Oakley, Kate. 2009. "Getting Out of Place: The Mobile Creative Class Takes on the Local. A UK Perspective on the Creative Class." In Creative Economies, Creative Cities: Asian-European Perspectives, edited by Lily Kong and Justin O'Connor, 121-134. Berlin: Springer.

Parker, Brenda. 2008. "Beyond the Class Act: Gender and Race in the 'Creative City' Discourse." Gender in an Urban World Research in Urban Sociology 9: 201-232.

"Parliamentary Group Addresses Gender Inequality in Design." 2006. Design Week, June 29.

Perrons, Diane. 2003. "The New Economy and the Work-Life Balance: Conceptual Explorations and a Case Study of New Media." Gender, Work \& Organization 10: 65-93.

Pratt, Andrew C., and Helen Jarvis. 2006. "Bringing It All Back Home: The Extensification and 'Overflowing' of Work. The Case of San Francisco's New Media Households." Geoforum 37: 331-339.

Pollock, Griselda. 1983. "Women, Art, and Ideology: Questions for Feminist Art Historians." Women's Studies Quarterly 4: $39-47$.

Puwar, Nirmal. 2004. Space Invaders: Race, Gender and Bodies Out of Place. Oxford: Berg.

Rantisi, Norma M. 2004. "The Designer in the City and the City in the Designer." In Cultural Industries and the Production of Culture, edited by D. Power and A. J. Scott, 91-109. London: Routledge.

Ranga, Marina, and Henry Etzkowitz. 2010. “Athena in the World of Techne:The Gender Dimension of Technology, Innovation and Entrepreneurship." Journal of Technology Management and Innovation. 5: 1-12.

Reimer, Suzanne, Steven Pinch, and Peter Sunley. 2008. "Design Spaces: Agglomeration and Creativity in British Design Agencies." Geografiska Annaler: Series B, Human Geography 90: 151-172.

Ross, Andrew. 2008. "The New Geography of Work: Power to the Precarious?" Theory, Culture and Society 25: 31-49.

Richardson, Anna. 2009. "Take the Long View (report on DW Annual Salary Survey)." Design Week, March 19.

Sang, Katherine J. C., Andrew R. J. Dainty, and Stephen G. Ison. 2014. "Gender in the UK Architectural Profession: (re) Producing and Challenging Hegemonic Masculinity." Work Employment and Society 28: 247-264.

Sayer, Andrew, and Kevin Morgan. 1985. "A Modern Industry in a Declining Region: Links between Method, Theory and Policy." In Politics and Method: Contrasting Studies in Industrial Geography, edited by D. Massey and R. Meegan, $145-168$. London: Methuen.

Sennett, Richard. 2009. The Craftsman. London: Penguin.

Sparke, Penny. 2009. The Genius of Design. London: Quadrile Publishing.

Sunley, Peter, Steven Pinch, and Suzanne Reimer. 2011. “Design Capital: Practice and Situated Learning in London Design Agencies." Transactions of the Institute of British Geographers 36: 377-392.

Sunley, Peter, Steven Pinch, Suzanne Reimer, and James Macmillen. 2008. "Innovation in A Creative Production System: The Case of Design." Journal of Economic Geography 8: 675-698.

Strati, Antonio. 1999. Organisation and Aesthetics. London: Sage.

Vinodrai, Tina. 2013. "Design in a Downturn? Creative Work, Labour Market Dynamics and Institutions in Comparative Perspective Cambridge." Journal of Regions Economy and Society 6: 159-176. http://www.oecd-ilibrary.org/science-andtechnology/science-technology-and-innovation-indicators-in-a-changing-world_9789264039667-en

Vinodrai, Tina, Meric S Gertler, Ray Lambert. 2007. "Capturing Design: Lessons from the United Kingdom and Canada." In Science, Technology and Innovation Indicators in a Changing World, 65-86. Paris: Organisation for Economic Cooperation and Development (OECD).

"Voxpop: Women in Design." 2006. Design Week, July 6.

"Women Can Make It to the Top, but Must Prove Their Worth ... Correspondence from Lynda Brockbank." 2008. Design Week, January 3.

Yanagisako, Sylvia Junko. 2002. Producing Culture and Capital: Family Firms in Italy. Princeton: Princeton University Press. 